\title{
Assessment of the health risk associated with exposure to heavy metals present in particulate matter deposition in the Małopolska Province
}

\author{
Jerzy Wieczorek ${ }^{1}$, Agnieszka Baran², Ewa Pawlik³ ${ }^{3}$ Izabela Mądro ${ }^{4}$, \\ Anna Gąsienica ${ }^{5}$, Iwona Wojtaszek ${ }^{6}$, Jacek Antonkiewicz ${ }^{7}$ \\ ${ }^{1}$ University of Agriculture in Krakow, Department of Agricultural and Environmental Chemistry; Krakow, Poland; \\ e-mail: jerzy.wieczorek@urk.edu.pl; ORCID ID: 0000-0001-7039-5974 \\ ${ }^{2}$ University of Agriculture in Krakow, Department of Agricultural and Environmental Chemistry; Krakow, Poland; \\ e-mail: Agnieszka.Baran@urk.edu.pl (corresponding author); ORCID ID: 0000-0003-4697-2959 \\ ${ }^{3}$ University of Agriculture in Krakow, Department of Agricultural and Environmental Chemistry; Krakow, Poland; \\ e-mail: ewapawewa@gmail.com \\ ${ }^{4}$ University of Agriculture in Krakow, Department of Agricultural and Environmental Chemistry; Krakow, Poland; \\ e-mail:iza.madro@interia.pl \\ ${ }^{5}$ University of Agriculture in Krakow, Department of Agricultural and Environmental Chemistry; Krakow, Poland; \\ e-mail:anka.gasienica@onet.pl \\ ${ }^{6}$ University of Agriculture in Krakow, Department of Agricultural and Environmental Chemistry; Krakow, Poland; \\ e-mail:wojtaszek94@o2.pl \\ ${ }^{7}$ University of Agriculture in Krakow, Department of Agricultural and Environmental Chemistry; Krakow, Poland; \\ e-mail: jacek.antonkiewicz@urk.edu.pl; ORCID ID: 0000-0002-8753-2119
}

(c) 2021 Authors. This is an open access publication, which can be used, distributed and reproduced in any medium according to the Creative Commons CC-BY 4.0 License requiring that the original work has been properly cited.

Received: 24 April 2021; accepted: 20 June 2021; first published online: 5 July 2021

\begin{abstract}
The aim of the study was to investigate the content of trace elements in deposited particulate matter and to estimate the health risk to Kraków inhabitants, caused by the exposure to heavy metals in particulate matter deposition. The qualitative and quantitative assessments of selected heavy metals in deposited particulate matter have been carried out in the city of Kraków (Małopolska, southern Poland, 5 measuring points) for seven months, between February and September 2017. A comparative study was conducted at the same time in Małopolska (5 measuring points). The deposited particulate matter was collected gravitationally, using measurement plates covered with aluminum foil and paraffin jelly. The largest deposition of particulate matter was found in May and June. The highest amount of deposited particulate matter and metals present in it was determined in Kraków. The Hazard Quotient (HQ) evaluation for non-carcinogenic effect showed low risk for each metal. In the case of lead in particulate matter, the carcinogenic risk value did not reach $10^{-6}$ hence this risk is acceptable. The total carcinogenic risk for all routes of exposure to cadmium was higher, indicating the risk of cancer in children and adults, with children more exposed. However, the carcinogenic risk for cadmium was also acceptable. The study showed that the problem of poor air quality concerns not only the city of Kraków, but also the entire Małopolska region. Elevated metal concentrations in particulate matter indicate the need for monitoring it in the air.
\end{abstract}

Keywords: air pollution, particulate matter deposition, heavy metals, health risk assessment 


\section{INTRODUCTION}

Over the last century, there has been a considerable industrial and urban development, whose effects are not neutral to the environment. The progress of civilization cannot be stopped, and its negative consequences for human health and the environment are becoming more and more visible (Ayangbenro \& Babalola 2017). One of them is elevated content of heavy metals in different parts of the environment, also in the atmosphere (Du et al. 2013, Sun et al. 2017, Wieczorek et al. 2017, Gruszecka-Kosowska 2018, Song et al. 2018). Concerns regarding the health and environmental impact of heavy metal content in particulate matter (PM) have increased in recent years (Hieu \& Lee 2010, Talbi et al. 2018, Anake et al. 2019). Sources of metals in particulate matter include: low emission, road transport, emissions from heavy industry related to coal and petroleum processing, emission from illegal burning of hazardous waste in household furnaces, and more natural sources such as forest fires or volcanic eruptions (Song et al. 2018). Air pollution in Poland is one of the highest in Europe. In addition, the EEA report (Air quality in Europe EEA (2018)) showed that many of polluted cities in the EU were located in Poland. Particulate matter is a particularly problematic substance in the air in terms of health (especially PM2.5 and PM10), as it contains heavy metals (Zhou et al. 2018). As a result of dry and wet deposition, particulate matter enters from the atmosphere into soil, waters, and precipitates onto the surface of plants (Correa et al. 2017). It also poses a direct threat to humans through inhalation or dermal contact. The impact of particulate matter on health depends especially on its amount, size, chemical composition as well as the length of exposure (Talbi et al. 2018). In the study of Talbi et al. (2018), wet deposition accounted for $54-71 \%$ of PM1-20 (1-20 $\mu \mathrm{m}$ particles) deposition and $76-86 \%$ of PM0.5-20 (0.5-20 $\mu \mathrm{m}$ particles) deposition (Talbi et al. 2018). Another study (Qi et al. 2005) showed significant correlation between the amount of particulate matter and particulate matter deposition as well as between the heavy metal content in particulate matter and particulate matter deposition.

The problem of dustiness is particularly noticeable in large urban agglomerations such as
Kraków in Poland (Gruszecka-Kosowska 2018, Kicińska \& Bożęcki 2018, Kicińska 2019). There are several causes of air pollution in Kraków: emissions from residential, municipal and industrial sectors, unfavorable location of the city, too many windless days, and development of ventilation channels. Long-term exposure to the heavy metal-polluted dust can cause chronic damage through inhalation, ingestion, and dermal contact. Heavy metals can cause both acute poisonings and chronic conditions. Chronic diseases are more dangerous - they are latent, but after some time they can cause mutagenic changes or damage the central nervous system (Shaheen et al. 2005, Sun et al. 2017). Additionally, they accumulate in organs such as the liver and kidneys, leading to their damage. Health risk assessment is the scientific evaluation of potential adverse health effects resulting from human exposure to a specific hazard (Anderson et al. 2002, Dziubanek et al. 2014, Anenberg et al. 2016, Anake et al. 2019).

The study aimed at: (1) determining the amount of particulate matter deposition and the content of heavy metals $(\mathrm{Cd}, \mathrm{Cu}, \mathrm{Ni}, \mathrm{Pb})$ in it depending on the season and place of measurement (Kraków; small towns: Brzesko, Krzeszowice, Wieliczka; villages: Białka Tatrzańska, Przysietnica), (2) estimating the health risk to Małopolska inhabitants, caused by the exposure to heavy metals in particulate matter through inhalation, ingestion, and dermal contact.

\section{MATERIAL AND METHODS}

\section{Location and time of sampling}

The qualitative and quantitative assessments of selected heavy metals in deposited particulate matter have been carried out in the city of Kraków (Małopolska, southern Poland) for seven months, between February and September 2017: February/March (period I); March/April (period II); April/May (period III); May/June (period IV); June/July (period V); July/August (period VI); August/September (period VII). The following measurement sites were established within the area of Kraków (Fig. 1): 1. The building of the Hugo Kołłątaj University of Agriculture in Krakow located at al. Adama Mickiewicza 21 (Adama Mickiewicza Avenue) in the $1^{\text {st }}$ district of Kraków - Stare Miasto (the Old Town); 2. Osiedle Tysiąclecia (District of a 1000-Year Anniversary) 
located in the $15^{\text {th }}$ district - Mistrzejowice; 3. Plac Szczepański (Szczepański Square) located in the $1^{\text {st }}$ district - Stare Miasto; 4. ul. Władysława Łokietka (Władysława Łokietka Street) located in the $5^{\text {th }}$ district - Krowodrza; 5. ul. Podbipięty (Podbipięty Street) in the $18^{\text {th }}$ district - Nowa Huta (Mogiła). A comparative study was conducted at the same time in Małopolska (Fig. 1). Sites of measurement of particulate matter deposition were set up in small towns, i.e., Krzeszowice $(30 \mathrm{~km}$ from Kraków), Wieliczka (15km from Kraków), Brzesko (60 km from Kraków) and in villages of Białka Tatrzańska (100 km from Kraków) and Przysietnica (115 km from Kraków). Measurement plates were placed near blocks of flats and single-family houses with no direct exposure to car traffic.

\section{Sampling}

The deposited particulate matter was collected gravitationally, using measurement plates covered with aluminum foil and paraffin jelly. This method enabled measurement of the amount of deposited particulate matter as well as its analysis for heavy metal content. The measurement plates were made using Petri dishes, which were coated with aluminum foil so as to obtain a smooth surface. Then, each plate was covered with an even layer of a sticky substance - paraffin jelly. After that, the plates were dried for 8 minutes at $42^{\circ} \mathrm{C}$ (Tomaszewska \& Olszowski 2012, Olszowski 2013). Two plates were placed at each measurement site. The plates were placed at a height of $2 \mathrm{~m}$ to minimize secondary emission from the soil. As a rule, after 28-day exposure, they were replaced with new ones and transported to a laboratory for analyzes. The plates were dried and properly labelled, and the diameter of each plate was measured. Plates prepared in this way were transported to the set locations in tightly closed and secured containers.

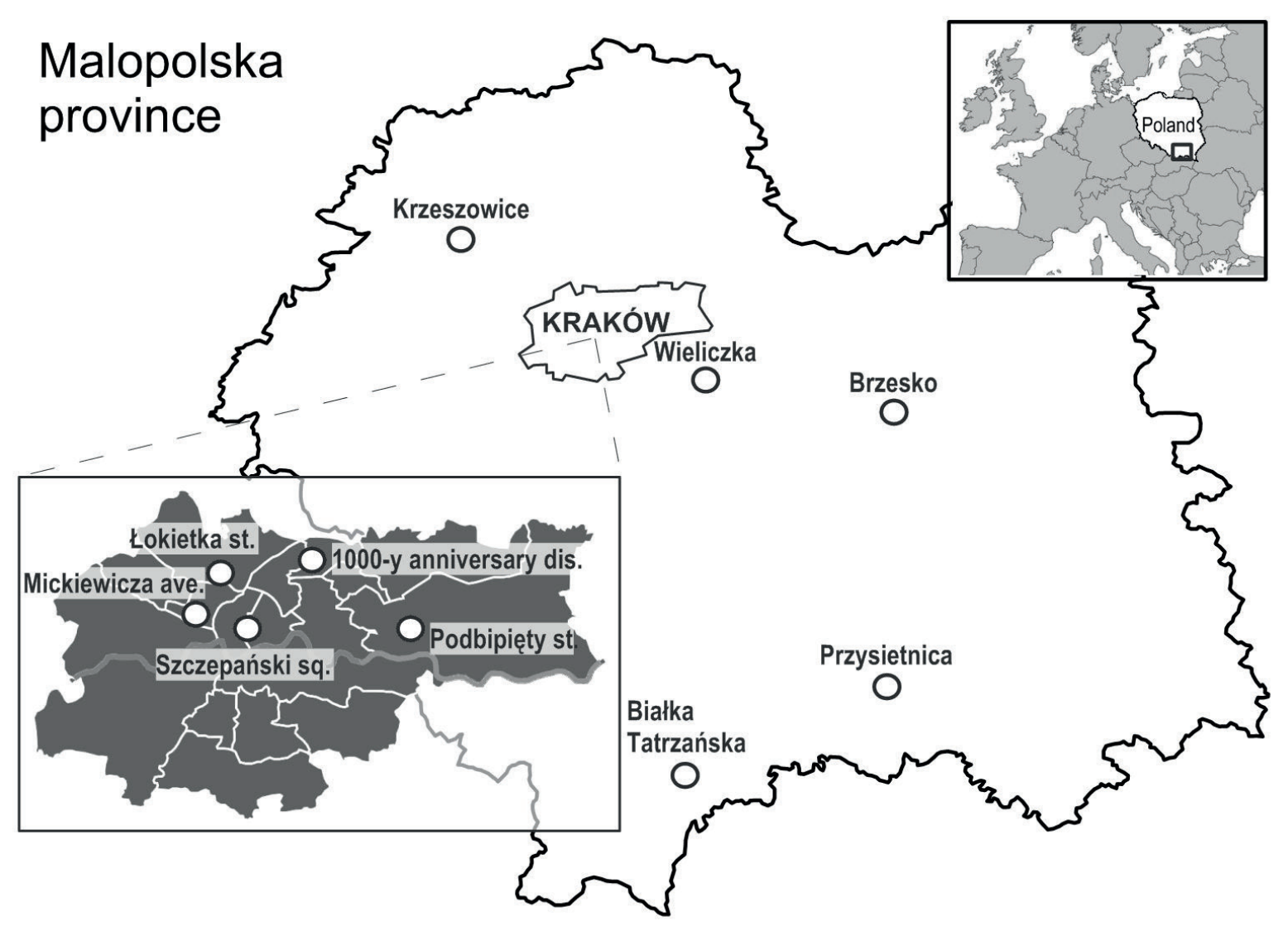

Fig. 1. Location of measurement points in Kraków and Małopolska Province 


\section{Chemical analysis methods}

\section{Particulate matter deposition}

After exposure, plates were transported to the laboratory, where substantial contaminants not related to the subject of the study were removed. Then, the plates were dried and analyzed. Aluminum foil was removed from the plates, soaked and successively rinsed with hexane in order to transfer particulate matter into the solution. The solution was transferred quantitatively onto previously weighed Whatman filters. Subsequently, the filters with particulate matter were dried to get rid of moisture. The successively dried filters were weighed, and the difference in the weight of empty filters and filters with particulate matter allowed to determine the amount of particulate matter on each plate. The filters were then placed in Teflon containers, to which concentrated $(65 \%)$ nitric acid $\left(\mathrm{HNO}_{3}\right)$ and $\mathrm{H}_{2} \mathrm{O}_{2}$ were added. The samples were digested in a closed microwave system (mls 1200 Pyro Asching, Milestone). The content of heavy metals was determined by the ICP-OES method using a PerkinElmer Optima $7300 \mathrm{DV}$ apparatus. The metal detection limits were as follows: $0.0027 \mathrm{mg} / \mathrm{L}$ for Cd; $0.0420 \mathrm{mg} / \mathrm{L}$ for $\mathrm{Pb} ; 0.0059 \mathrm{mg} / \mathrm{L}$ for $\mathrm{Zn} ; 0.0150 \mathrm{mg} / \mathrm{L}$ for $\mathrm{Ni}$, and $0.0097 \mathrm{mg} / \mathrm{L}$ for $\mathrm{Cu}$.

\section{Methodology of health risk assessment}

A health risk is the probability of negative health effects due to contact with a given agent, metals in this case. The applied health risk assessment method was sourced from the procedures of the United States Environmental Protection Agency (US EPA) (US EPA 2004, Wcisło et al. 2016). Health risk was investigated in two categories: as a carcinogenic risk and as a non-carcinogenic risk. The general population of children and adults was used for calculations. Health risk was calculated for three ways of exposure: accidental ingestion of particulate matter (1), contact through dermal absorption of particulate matter (2), and inhalation of particulate matter molecules (3):

$$
\begin{aligned}
& C I=\frac{C S \times E F \times E D \times I R_{0} \times C F_{1}}{B W \times A T} \\
& A D=\frac{C S \times E F \times E D \times S A \times A F \times A B S_{\mathrm{d}} \times C F_{1}}{B W \times A T}
\end{aligned}
$$

$$
P I=\frac{C S \times E F \times E D \times I R_{1} \times \frac{1}{P E F}}{B W \times A T}
$$

where: $C I$ - dose of chemical substances taken up through the alimentary route $[\mathrm{mg} / \mathrm{kg} / \mathrm{day}]$, CS concentration of substances in particular matter $[\mathrm{mg} / \mathrm{kg}$ ], EF - exposure frequency [days/year], $E D$ - exposure duration [years], $I R_{0}$ - twentyfour-hour accidental dust ingestion rate [mg/day], $B W$ - body weight [kg], $A T$ - exposure averaging time [days] $=E D \times 365$ days/year for non-carcinogenic substances, $A T=70$ years $\times 365$ days/year for carcinogenic substances, $C F_{1}$ - conversion factor $\left[10^{-6} \mathrm{~kg} / \mathrm{mg}\right], A D$ - dermally absorbed dose of a substance $[\mathrm{mg} / \mathrm{kg} /$ day], $S A$ - skin surface area in contact with dust $\left[\mathrm{cm}^{2}\right], A B S_{\mathrm{d}}$ - dermal absorption factor, specific for the substance [unitless], PI - dose of a chemical absorbed through the respiratory route by inhaling particles of dust [mg/ $\mathrm{kg} / \mathrm{day}], I R_{1}$ - inhalation rate, value of daily lung ventilation $\left[\mathrm{m}^{3} / \mathrm{day}\right], P E F$ - dust particle emission factor $\left[\mathrm{m}^{3} / \mathrm{kg}\right]$ (Tab. 1$)$.

\section{Table 1}

Formulas and exposure parameters used under the residential exposure scenarios

\begin{tabular}{|l|c|c|c|}
\hline $\begin{array}{c}\text { Exposure } \\
\text { parameters }\end{array}$ & Unit & Child & Adult \\
\hline$A F$ & $\mathrm{mg} / \mathrm{cm}^{2} / \mathrm{day}$ & 0.2 & 0.07 \\
\hline$A T_{1}$ & $E D \times 365$ & 2190 & 10950 \\
\hline$A T_{2}$ & $E D \times 365$ & 25550 & 25550 \\
\hline$B W$ & $\mathrm{~kg}$ & 15 & 70 \\
\hline$C F_{1}$ & - & 0.000001 & 0.000001 \\
\hline$E D$ & year & 6 & 30 \\
\hline$E F$ & $\mathrm{day} / \mathrm{year}$ & 350 & 350 \\
\hline$I R_{0}$ & $\mathrm{mg} / \mathrm{day}$ & 200 & 100 \\
\hline$I R_{1}$ & $\mathrm{~m}^{3} / \mathrm{day}$ & 10 & 20 \\
\hline$P E F$ & $\mathrm{~m}^{3} / \mathrm{kg}$ & $1.36 \mathrm{E}+09$ & $1.36 \mathrm{E}+09$ \\
\hline$S A$ & $\mathrm{~cm}{ }^{2}$ & 2800 & 5700 \\
\hline
\end{tabular}

$A F$ - coefficient of dust adhesion to the skin $\left[\mathrm{mg} / \mathrm{cm}^{2} /\right.$ day $], A T_{1}-\mathrm{ex}-$ posure averaging time [days] $=E D \times 365$ days/year for non-carcinogenic substances, $A T_{2}=70$ years $\times 365$ days/year for carcinogenic substances, $B W$ - body weight [kg], $C F_{1}$ - conversion factor $\left[10^{-6} \mathrm{~kg} / \mathrm{mg}\right]$, $E D$ - exposure duration [years], $E F$ - exposure frequency [days/year], $I R_{0}$ - twenty-four-hour accidental dust ingestion rate [mg/day], $I R_{1}-$ twenty-four-hour accidental particular matter ingestion rate [mg/day], $P E F$ - dust particle emission factor $\left[\mathrm{m}^{3} / \mathrm{kg}\right], S A-$ skin surface area in contact with dust $\left[\mathrm{cm}^{2}\right]$. 
Table 2

Formulas and toxicological data required for the calculation of carcinogenic and non-carcinogenic risks

\begin{tabular}{|l|c|c|c|c|c|}
\hline \multicolumn{1}{|c|}{ Heavy metal } & $\begin{array}{c}R f D_{\text {ing derm }} \\
{[\mathbf{m g} / \mathbf{k g} / \mathbf{d}]}\end{array}$ & $\begin{array}{c}R f D_{\text {inhal }} \\
{\left[\mathbf{m g} / \mathbf{m}^{3}\right]}\end{array}$ & $\begin{array}{c}S F_{\text {ing derm }} \\
{[\mathbf{m g} / \mathbf{k g} / \mathbf{d}]^{-1}}\end{array}$ & $\begin{array}{c}S F_{\text {inhal }} \\
{\left[\mathbf{m g}^{3}\right]^{-1}}\end{array}$ \\
\hline $\mathrm{Cd}$ & $1.00 \mathrm{E}-03$ & $1.00 \mathrm{E}-05$ & $6.10 \mathrm{E}+00$ & $1.80 \mathrm{E}+00$ \\
\hline $\mathrm{Cu}$ & $4.00 \mathrm{E}-02$ & $4.00 \mathrm{E}-02$ & - & - \\
\hline $\mathrm{Ni}$ & $2.00 \mathrm{E}-02$ & $9.00 \mathrm{E}-05$ & - & 0.01 \\
\hline $\mathrm{Pb}$ & $3.60 \mathrm{E}-03$ & $3.60 \mathrm{E}-03$ & $8.50 \mathrm{E}-03$ & $2.60 \mathrm{E}-01$ \\
\hline
\end{tabular}

$R f D$ - reference dose for a given exposure route, $S F$ - slope factor for a given exposure route, ing - ingestion, derm - dermal, inhal - inhalation, $A B S_{\mathrm{d}}$ - dermal absorption factor, specific for the substance [unitless].

The second stage was to estimate the carcinogenic and non-carcinogenic risks. The non-carcinogenic risk is characterized by the dose calculated from respective exposure routes and by the reference dose for metals. This health risk is determined by the hazard quotient (HQ):

$$
H Q=\frac{C I \text { or } A D \text { or } P I}{R f D}
$$

where: $H Q$ - hazard quotient, $C I$ or $A D$ or $P I$ chronic daily intake, $R f D$ - reference dose for a given exposure route (Tab. 2).

Carcinogenic risk determines the probability of cancer in the entire life. It is calculated using the following formula:

$C R=C I$ or $A D$ or $P I \times S F$

where: $C R$ - carcinogenic risk arising from exposure to a given carcinogen through a specific exposure route, $C I$ or $A D$ or $P I$ - chronic daily intake, averaged over 70 years of human life, $S F$ - slope factor for a given exposure route (Tab. 2).

The third stage involved summing up the obtained results of carcinogenic risk for all exposure routes $\left(C R_{\text {all }}\right)$; the same applied to the non-carcinogenic risk $\left(H Q_{\text {all }}\right)$. The sums revealed the potential health risk associated with exposure to heavy metals in particulate matter deposition. The carcinogenic risk from 1.00E-04 to $1.00 \mathrm{E}-06$ is acceptable. On the other hand, the permissible non-carcinogenic risk is such for which $H Q<1$, if $H Q>1$, health risk appears (Wcisło et al. 2016).

\section{RESULTS AND DISCUSSION}

\section{Particulate matter deposition and content of metals}

Deposited particulate matter in the period from February to September 2017 in selected locations in Kraków and Małopolska Province is presented in Table 3. In Kraków, as a rule, the highest particulate matter deposition was observed at the site at al. A. Mickiewicza: from $6.02(\mathrm{~V})$ to 13.81 (VI) $\mathrm{g} / \mathrm{m}^{2} /$ month (Tab. 3). Only in the third period thehighestamount of particulate matter was recorded in Nowa Huta (III $-18.73 \mathrm{~g} / \mathrm{m}^{2} /$ month). It is not possible to determine unambiguously where the particulate matter deposition was the lowest, as its amounts varied strongly in individual locations. In comparison to other locations, the least varied amount of particulate matter accumulated in the studied period was observed in $\mathrm{Mi}$ strzejowice: from 4.10 (V) to 9.61 (IV) $\mathrm{g} / \mathrm{m}^{2} / \mathrm{month}$ (Tab. 3). During the study period, the highest amount of particulate matter at the majority of the measurement sites in Kraków fell in period IV (May/June). Depending on the location, the particulate matter deposition in this period ranged from $5.36 \mathrm{~g} / \mathrm{m}^{2} /$ month (Nowa Huta) to $23.8 \mathrm{~g} / \mathrm{m}^{2} /$ month (al. A. Mickiewicza) (Tab. 3). Relatively the lowest amounts of particulate matter deposited (3.65$6.02 \mathrm{~g} / \mathrm{m}^{2} / \mathrm{month}$ ) were determined in period $\mathrm{V}$ (June/July). In the case of locations in Małopolska, similarly to Kraków, the largest amounts of particulate matter deposited were measured in period IV (May/June): from 8.98 to $20.34 \mathrm{~g} / \mathrm{m}^{2} /$ month (small towns) and from 6.67 to $18.15 \mathrm{~g} / \mathrm{m}^{2} /$ month 
(villages), respectively. For the majority of the study period, substantial deposition of particulate matter persisted in Krzeszowice (7.97$20.34 \mathrm{~g} / \mathrm{m}^{2} /$ month) (Tab. 3). Only in two periods - period III (April/May) and period IV (May/ June) - the largest amounts of particulate matter deposited were recorded in Kraków. In the case of smaller towns and in rural areas, the amounts of particulate matter deposited remained at a similar level or even exceeded the amounts of particulate matter collected in Kraków. This indicates that the problem of dustiness equally affects Kraków and the entire province. On average, the deposited particulate matter in Małopolska in the period from February to September 2017 remained at $8 \mathrm{~g} / \mathrm{m}^{2} / \mathrm{month}$. According to a study conducted using the same method in south-western Poland in 2011, the amount of particulate matter between January and October remained at $11 \mathrm{~g} / \mathrm{m}^{2} /$ month (Tomaszewska \& Olszowski 2012).

Table 3

Deposited particulate matter $\left[\mathrm{g} / \mathrm{m}^{2} /\right.$ month $\left.\pm S D\right]$

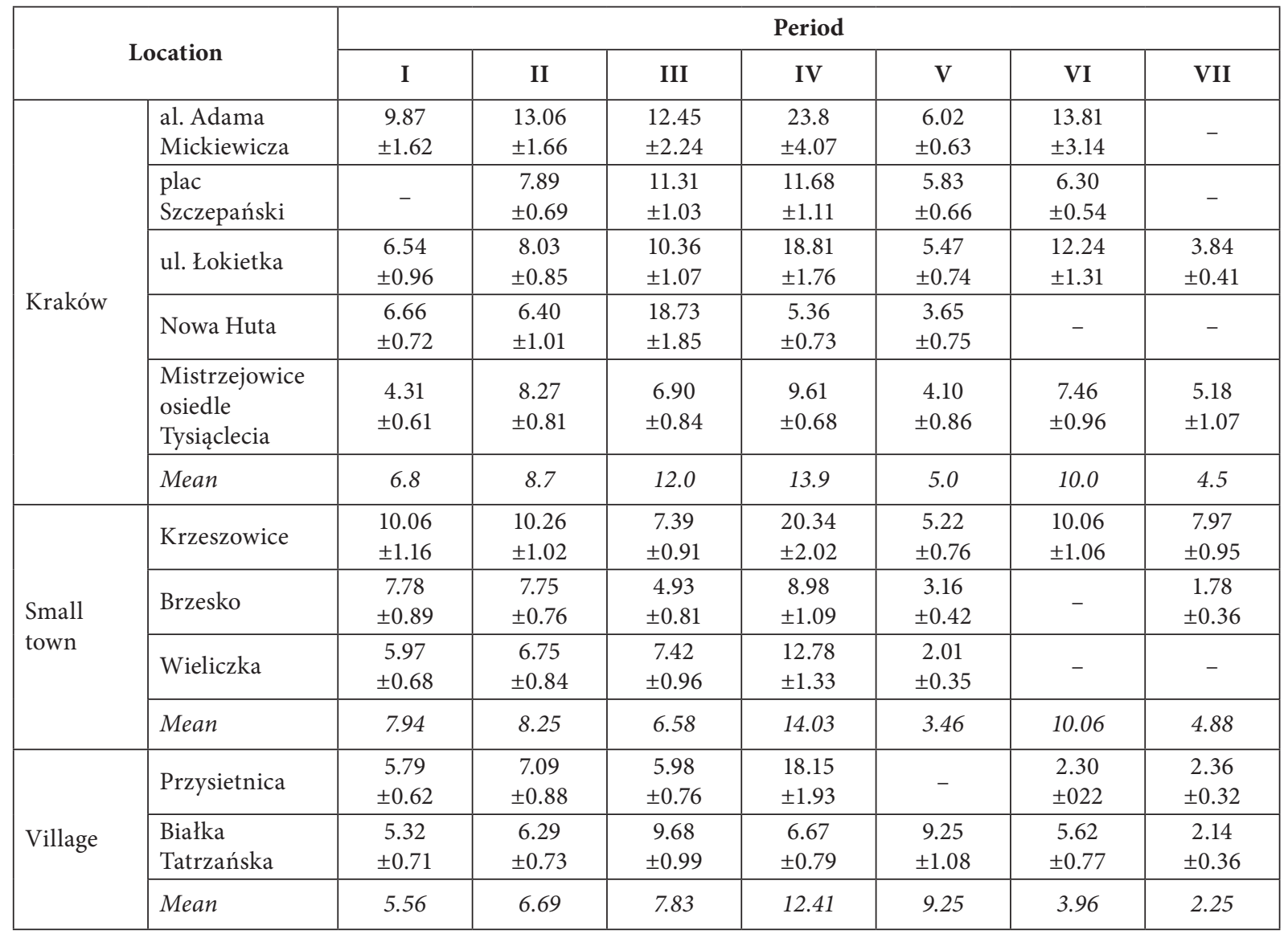

Table 4 shows the content of selected metals in particulate matter from Kraków and Małopolska at specific measurement sites and periods. In Kraków, the highest cadmium content in particulate matter was determined in March/April (3.37-6.38 $\mu \mathrm{g} / \mathrm{g} \mathrm{DM})$, and the lowest in July/August in the samples collected at ul. Władysława Łokietka $(0.38 \mu \mathrm{g} / \mathrm{g} \mathrm{DM})$. The analysis of the results obtained for the Małopolska region allowed to state that the highest cadmium content in particulate matter occurred in Przysietnica in March/April (42.29 $\mu \mathrm{g} / \mathrm{g} \mathrm{DM})$. In turn, the lowest cadmium content was observed in particulate matter collected in Krzeszowice in July/August $(0.34 \mu \mathrm{g} / \mathrm{g} \mathrm{DM})$. The study revealed that the average cadmium content in Kraków in cool months was 
3.62 (period I); 4.31 (period II), and $4.53 \mu \mathrm{g} / \mathrm{g} \mathrm{DM}$ (period III), whereas in warm months - from 0.91 (period VI) to $2.16 \mu \mathrm{g} / \mathrm{g}$ DM (period V) (Tab. 4). Compared to the study conducted in Dylaki village, the cadmium content in particulate matter in Kraków was higher in the winter period, and lower in the summer period (Tomaszewska \& Olszowski 2012). On average, in the period from February to September, the cadmium content in particulate matter in Kraków remained at $2.7 \mu \mathrm{g} / \mathrm{g} \mathrm{DM}$ in Kraków and at $5.8 \mu \mathrm{g} / \mathrm{g} \mathrm{DM}$ at other sites of Małopolska. According to the study conducted between November 2014 and January 2015 as well as between November 2015 and January 2016, the cadmium level in particulate matter in the center of Kraków remained at $1.2 \mu \mathrm{g} / \mathrm{g}$ DM (Gruszecka-Kosowska \& Wdowin 2016).

The highest lead content in Kraków was observed in deposited particulate matter from Mistrzejowice in the period from June to July: $149.4 \mu \mathrm{g} / \mathrm{g}$ DM (Tab. 4). The lowest lead content was found in deposited particulate matter at the study site located at plac Szczepański $(3.0 \mu \mathrm{g} / \mathrm{g}$ DM) at the turn of May and June. In the case of Małopolska, the highest lead content in the collected particulate matter was found in Wieliczka in May/ June $(43.5 \mu \mathrm{g} / \mathrm{g} D \mathrm{DM})$, and the lowest also in that period, but in Kraków. On average, in the period from February to September, the lead content in particulate matter remained at $38.2 \mu \mathrm{g} / \mathrm{g} \mathrm{DM}$ in Kraków and at $38.5 \mu \mathrm{g} / \mathrm{g} \mathrm{DM}$ at other sites of Małopolska. According to the study conducted between November 2014 and January 2015 as well as between November 2015 and January 2016, the lead level in particulate matter in the center of Kraków remained at $88 \mu \mathrm{g} / \mathrm{g}$ DM (Gruszecka-Kosowska \& Wdowin 2016). In the majority of periods, the highest copper content in particulate matter in Kraków was found at al. Adama Mickiewicza (from 124.0 to $2253.8 \mu \mathrm{g} / \mathrm{g}$ DM). Only in period IV, the copper content in particulate matter from Nowa Huta was significantly higher than in other locations in Kraków (Tab. 4). Analysis of the copper content in particulate matter against the deposition period allowed to establish that samples from period V (June/May) had the highest element content at all sites. For most of the time, the copper content in particulate matter in individual locations and periods varied strongly. In the case of locations in the Małopolska region, high concentrations of copper in particulate matter in each period were recorded in Brzesko (97.4-2014.5 $\mu \mathrm{g} / \mathrm{g}$ DM) and in Kraków (7.6-2253.8 $\mu \mathrm{g} / \mathrm{g} \mathrm{DM})$. Compared to other locations, a relatively low copper content in particulate matter was observed in rural areas (24.7$211.9 \mu \mathrm{g} / \mathrm{g}$ DM). The highest copper content was found in particulate matter in period V, in all locations. It can be observed that the copper contents in particulate matter from Wieliczka, Brzesko, Kraków and Krzeszowice in that period were very high. On average, in the period from February to September 2017 (excluding period V), the copper content in particulate matter remained at $175 \mu \mathrm{g} / \mathrm{g}$ DM in Kraków and at $143 \mu \mathrm{g} / \mathrm{g}$ DM at other sites of Małopolska. According to the study conducted between November 2014 and January 2015 as well as between November 2015 and January 2016, the copper level in particulate matter in the center of Kraków remained at $185 \mu \mathrm{g} / \mathrm{g}$ DM (Tomaszewska \& Olszowski 2012). Of the seven periods, the lowest nickel content in the studied deposited particulate matter from Kraków was recorded in Nowa Huta at the turn of March and April (3.5-41.1 $\mu \mathrm{g} / \mathrm{g} \mathrm{DM})$, whereas the highest in July/August at plac Szczepański (133.2 $\mu \mathrm{g} / \mathrm{g}$ DM) (Tab. 4). In the case of measurement sites in Małopolska, the highest nickel content in particulate matter was found in Kraków in July/August, and the lowest in Przysietnica in May/June. On average, in the period from February to September, the nickel content in particulate matter remained at $23 \mu \mathrm{g} / \mathrm{g}$ DM in Kraków and at $19 \mu \mathrm{g} / \mathrm{g} D M$ at other sites of Małopolska. According to the study conducted between November 2014 and January 2015 as well as between November 2015 and January 2016, the nickel level in particulate matter in the center of Kraków remained at 23.1 $\mu \mathrm{g} / \mathrm{g}$ DM (Gruszecka-Kosowska \& Wdowin 2016).

To date, several studies have been conducted on the content of trace elements, distribution and source identification of deposited particulate matter collected in many cities and towns (Zeng et al. 2019). However, there is no information on potentially toxic elements in the deposited particulate matter. The WHO has found that people living in cities and towns suffer from certain health issues due to prolonged exposure to heavy metals. 
Table 4

Content of metals in particulate matter $[\mu g / g D M \pm S D]$

\begin{tabular}{|c|c|c|c|c|c|c|c|c|}
\hline \multirow{2}{*}{\multicolumn{2}{|c|}{ Location }} & \multicolumn{7}{|c|}{ Period } \\
\hline & & I & II & III & IV & V & VI & VII \\
\hline \multicolumn{9}{|c|}{ Cd } \\
\hline \multirow{6}{*}{ Kraków } & $\begin{array}{l}\text { al. Adama } \\
\text { Mickiewicza }\end{array}$ & $\begin{array}{c}4.58 \\
\pm 0.44\end{array}$ & $\begin{array}{c}4.42 \\
\pm 0.24\end{array}$ & $\begin{array}{c}3.88 \\
\pm 0.31\end{array}$ & $\begin{array}{c}2.25 \\
\pm 0.18\end{array}$ & $\begin{array}{c}0.84 \\
\pm 0.09\end{array}$ & $\begin{array}{c}0.69 \\
\pm 0.06\end{array}$ & $\begin{array}{c}0.69 \\
\pm 0.07\end{array}$ \\
\hline & $\begin{array}{l}\text { plac } \\
\text { Szczepański }\end{array}$ & $\begin{array}{c}2.44 \\
\pm 0.21\end{array}$ & $\begin{array}{c}2.66 \\
\pm 0.14\end{array}$ & $\begin{array}{c}4.67 \\
\pm 0.25\end{array}$ & $\begin{array}{c}0.47 \\
\pm 0.09\end{array}$ & $\begin{array}{c}2.49 \\
\pm 0.14\end{array}$ & $\begin{array}{c}1.86 \\
\pm 0.11\end{array}$ & $\begin{array}{c}1.86 \\
\pm 0.13\end{array}$ \\
\hline & ul. Łokietka & $\begin{array}{c}3.79 \\
\pm 0.22\end{array}$ & $\begin{array}{c}8.79 \\
\pm 0.65\end{array}$ & $\begin{array}{c}4.34 \\
\pm 0.18\end{array}$ & $\begin{array}{c}1.24 \\
\pm 0.06\end{array}$ & $\begin{array}{c}0.71 \\
\pm 0.05\end{array}$ & $\begin{array}{c}0.38 \\
\pm 0.04\end{array}$ & $\begin{array}{c}0.93 \\
\pm 0.11\end{array}$ \\
\hline & Nowa Huta & $\begin{array}{c}3.39 \\
\pm 0.17\end{array}$ & $\begin{array}{c}3.60 \\
\pm 0.24\end{array}$ & $\begin{array}{c}3.37 \\
\pm 0.15\end{array}$ & $\begin{array}{c}0.67 \\
\pm 0.31\end{array}$ & $\begin{array}{c}1.07 \\
\pm 0.08\end{array}$ & - & - \\
\hline & $\begin{array}{l}\text { Mistrzejowice } \\
\text { osiedle } \\
\text { Tysiąclecia }\end{array}$ & $\begin{array}{c}3.91 \\
\pm 0.33\end{array}$ & $\begin{array}{c}2.10 \\
\pm 0.44\end{array}$ & $\begin{array}{c}6.38 \\
\pm 0.46\end{array}$ & $\begin{array}{c}1.26 \\
\pm 0.05\end{array}$ & $\begin{array}{c}5.68 \\
\pm 0.36\end{array}$ & $\begin{array}{c}0.72 \\
\pm 0.07\end{array}$ & - \\
\hline & Mean & 3.62 & 4.31 & 4.53 & 1.18 & 2.16 & 0.91 & 1.16 \\
\hline \multirow{4}{*}{$\begin{array}{l}\text { Small } \\
\text { town }\end{array}$} & Krzeszowice & $\begin{array}{c}2.58 \\
\pm 0.17\end{array}$ & $\begin{array}{c}7.21 \\
\pm 0.22\end{array}$ & $\begin{array}{c}7.34 \\
\pm 0.37\end{array}$ & $\begin{array}{c}1.92 \\
\pm 0.12\end{array}$ & $\begin{array}{c}1.10 \\
\pm 0.09\end{array}$ & $\begin{array}{c}0.34 \\
\pm 0.02\end{array}$ & $\begin{array}{c}0.35 \\
\pm 0.02\end{array}$ \\
\hline & Brzesko & $\begin{array}{c}3.58 \\
\pm 0.38\end{array}$ & $\begin{array}{l}15.56 \\
\pm 0.91\end{array}$ & $\begin{array}{c}3.84 \\
\pm 0.28\end{array}$ & $\begin{array}{c}3.31 \\
\pm 0.09\end{array}$ & $\begin{array}{c}1.15 \\
\pm 0.08\end{array}$ & - & - \\
\hline & Wieliczka & $\begin{array}{c}3.33 \\
\pm 0.18\end{array}$ & $\begin{array}{l}23.92 \\
\pm 0.91\end{array}$ & $\begin{array}{c}6.01 \\
\pm 0.08\end{array}$ & $\begin{array}{c}3.94 \\
\pm 0.08\end{array}$ & $\begin{array}{c}1.89 \\
\pm 0.04 \\
\end{array}$ & - & - \\
\hline & Mean & 3.16 & 15.56 & 5.73 & 3.06 & 1.38 & 0.34 & 0.35 \\
\hline \multirow{3}{*}{ Village } & Przysietnica & $\begin{array}{r}2.37 \\
\pm 0.16 \\
\end{array}$ & $\begin{array}{r}42.29 \\
\pm 1.15 \\
\end{array}$ & $\begin{array}{r}4.29 \\
\pm 0.43 \\
\end{array}$ & $\begin{array}{c}0.82 \\
\pm 0.04 \\
\end{array}$ & - & - & $\begin{array}{r}1.91 \\
\pm 0.12 \\
\end{array}$ \\
\hline & $\begin{array}{l}\text { Białka } \\
\text { Tatrzańska }\end{array}$ & $\begin{array}{c}2.89 \\
\pm 0.29 \\
\end{array}$ & $\begin{array}{l}14.76 \\
\pm 0.92 \\
\end{array}$ & $\begin{array}{c}2.41 \\
\pm 0.19 \\
\end{array}$ & $\begin{array}{c}5.17 \\
\pm 0.46\end{array}$ & $\begin{array}{c}0.42 \\
\pm 0.03 \\
\end{array}$ & $\begin{array}{c}0.70 \\
\pm 0.03 \\
\end{array}$ & - \\
\hline & Mean & 2.63 & 28.53 & 3.35 & 3.00 & 0.42 & 0.70 & 1.91 \\
\hline \multicolumn{9}{|c|}{$\mathbf{P b}$} \\
\hline \multirow{6}{*}{ Kraków } & $\begin{array}{l}\text { al. Adama } \\
\text { Mickiewicza }\end{array}$ & $\begin{array}{l}45.1 \\
\pm 2.5\end{array}$ & $\begin{array}{l}23.0 \\
\pm 2.1\end{array}$ & $\begin{array}{l}33.3 \\
\pm 1.5 \\
\end{array}$ & $\begin{array}{l}23.1 \\
\pm 2.7\end{array}$ & $\begin{array}{l}51.4 \\
\pm 3.5\end{array}$ & $\begin{array}{l}46.8 \\
\pm 3.6\end{array}$ & - \\
\hline & $\begin{array}{l}\text { plac } \\
\text { Szczepański }\end{array}$ & - & $\begin{array}{l}31.4 \\
\pm 1.5\end{array}$ & $\begin{array}{l}20.9 \\
\pm 0.8\end{array}$ & $\begin{array}{c}3.0 \\
\pm 0.4\end{array}$ & $\begin{array}{l}75.3 \\
\pm 3.6\end{array}$ & $\begin{array}{l}51.2 \\
\pm 2.9\end{array}$ & - \\
\hline & ul. Łokietka & $\begin{array}{l}29.1 \\
\pm 2.0\end{array}$ & $\begin{array}{l}38.7 \\
\pm 2.7\end{array}$ & $\begin{array}{r}48.6 \\
\pm 3.4\end{array}$ & $\begin{array}{l}28.7 \\
\pm 2.4\end{array}$ & $\begin{array}{l}19.6 \\
\pm 2.0\end{array}$ & $\begin{array}{l}24.3 \\
\pm 2.1 \\
\end{array}$ & $\begin{array}{l}28.0 \\
\pm 2.0\end{array}$ \\
\hline & Nowa Huta & $\begin{array}{l}32.7 \\
\pm 2.9 \\
\end{array}$ & $\begin{array}{l}16.9 \\
\pm 1.3 \\
\end{array}$ & $\begin{array}{l}25.8 \\
\pm 2.6 \\
\end{array}$ & $\begin{array}{l}20.6 \\
\pm 1.8 \\
\end{array}$ & $\begin{array}{l}48.9 \\
\pm 2.1 \\
\end{array}$ & - & - \\
\hline & $\begin{array}{l}\text { Mistrzejowice } \\
\text { osiedle } \\
\text { Tysiąclecia }\end{array}$ & $\begin{array}{l}45.5 \\
\pm 3.5\end{array}$ & $\begin{array}{l}41.8 \\
\pm 2.9\end{array}$ & $\begin{array}{l}29.6 \\
\pm 2.0\end{array}$ & $\begin{array}{l}36.5 \\
\pm 2.1\end{array}$ & $\begin{array}{c}149.4 \\
\pm 5.5\end{array}$ & $\begin{array}{l}27.1 \\
\pm 2.1\end{array}$ & $\begin{array}{l}49.7 \\
\pm 2.9\end{array}$ \\
\hline & Mean & 38.10 & 30.36 & 34.33 & 27.23 & 67.33 & 32.73 & 38.85 \\
\hline \multirow{4}{*}{$\begin{array}{l}\text { Small } \\
\text { town }\end{array}$} & Krzeszowice & $\begin{array}{l}27.5 \\
\pm 2.6\end{array}$ & $\begin{array}{l}43.6 \\
\pm 4.1\end{array}$ & $\begin{array}{l}69.7 \\
\pm 4.4\end{array}$ & $\begin{array}{l}29.6 \\
\pm 2.1\end{array}$ & $\begin{array}{l}25.3 \\
\pm 2.1\end{array}$ & $\begin{array}{l}59.8 \\
\pm 3.2\end{array}$ & $\begin{array}{l}17.8 \\
\pm 1.5\end{array}$ \\
\hline & Brzesko & $\begin{array}{r}43.3 \\
\pm 3.5 \\
\end{array}$ & $\begin{array}{l}32.5 \\
\pm 2.4 \\
\end{array}$ & $\begin{array}{l}26.9 \\
\pm 1.3 \\
\end{array}$ & $\begin{array}{l}61.6 \\
\pm 2.5\end{array}$ & $\begin{array}{l}41.6 \\
\pm 3.6 \\
\end{array}$ & - & $\begin{array}{l}36.2 \\
\pm 2.7 \\
\end{array}$ \\
\hline & Wieliczka & $\begin{array}{r}61.3 \\
\pm 4.5 \\
\end{array}$ & $\begin{array}{l}18.4 \\
\pm 2.1 \\
\end{array}$ & $\begin{array}{l}18.0 \\
\pm 1.2 \\
\end{array}$ & $\begin{array}{l}117.5 \\
\pm 5.1 \\
\end{array}$ & $\begin{array}{l}43.5 \\
\pm 2.2 \\
\end{array}$ & - & - \\
\hline & Mean & 44.0 & 31.50 & 38.20 & 69.57 & 36.80 & 59.80 & 27.00 \\
\hline \multirow{3}{*}{ Village } & Przysietnica & $\begin{array}{r}36.5 \\
\pm 2.9 \\
\end{array}$ & $\begin{array}{l}22.5 \\
\pm 1.6 \\
\end{array}$ & $\begin{array}{l}25.0 \\
\pm 2.5 \\
\end{array}$ & $\begin{array}{l}13.6 \\
\pm 1.0 \\
\end{array}$ & $\begin{array}{l}77.1 \\
\pm 3.3 \\
\end{array}$ & $\begin{array}{l}50.5 \\
\pm 2.9\end{array}$ & $\begin{array}{l}47.3 \\
\pm 3.1 \\
\end{array}$ \\
\hline & $\begin{array}{l}\text { Białka } \\
\text { Tatrzańska }\end{array}$ & $\begin{array}{l}24.0 \\
\pm 2.0 \\
\end{array}$ & $\begin{array}{l}16.8 \\
\pm 0.7 \\
\end{array}$ & $\begin{array}{l}11.4 \\
\pm 1.0 \\
\end{array}$ & $\begin{array}{l}64.5 \\
\pm 3.6 \\
\end{array}$ & $\begin{array}{l}37.7 \\
\pm 2.5 \\
\end{array}$ & $\begin{array}{l}20.3 \\
\pm 1.7 \\
\end{array}$ & $\begin{array}{l}55.9 \\
\pm 3.9 \\
\end{array}$ \\
\hline & Mean & 30.25 & 19.65 & 18.20 & 39.05 & 57.40 & 35.40 & 51.60 \\
\hline
\end{tabular}


Table 4 cont.

\begin{tabular}{|c|c|c|c|c|c|c|c|c|}
\hline \multicolumn{9}{|c|}{$\mathrm{Cu}$} \\
\hline \multirow{6}{*}{ Kraków } & $\begin{array}{l}\text { al. Adama } \\
\text { Mickiewicza }\end{array}$ & $\begin{array}{c}280.5 \\
\pm 7.5\end{array}$ & $\begin{array}{l}124.0 \\
\pm 4.6\end{array}$ & $\begin{array}{l}331.5 \\
\pm 7.4\end{array}$ & $\begin{array}{l}171.6 \\
\pm 6.5\end{array}$ & $\begin{array}{c}2253.8 \\
\pm 12.5\end{array}$ & $\begin{array}{c}283.2 \\
\pm 6.1\end{array}$ & - \\
\hline & $\begin{array}{l}\text { plac } \\
\text { Szczepański }\end{array}$ & $\begin{array}{l}34.8 \\
\pm 2.0\end{array}$ & $\begin{array}{l}44.6 \\
\pm 2.1 \\
\end{array}$ & $\begin{array}{l}127.2 \\
\pm 3.4 \\
\end{array}$ & $\begin{array}{l}59.1 \\
\pm 2.2\end{array}$ & $\begin{array}{l}857.9 \\
\pm 9.6 \\
\end{array}$ & $\begin{array}{c}206.5 \\
\pm 6.3 \\
\end{array}$ & - \\
\hline & ul. Łokietka & $\begin{array}{l}52.8 \\
\pm 3.1\end{array}$ & $\begin{array}{l}117.5 \\
\pm 3.3\end{array}$ & $\begin{array}{c}207.9 \\
\pm 3.4\end{array}$ & $\begin{array}{r}74.9 \\
\pm 2.1\end{array}$ & $\begin{array}{c}644.8 \\
\pm 5.5\end{array}$ & $\begin{array}{l}63.8 \\
\pm 2.6\end{array}$ & $\begin{array}{l}114.9 \\
\pm 4.5\end{array}$ \\
\hline & Nowa Huta & $\begin{array}{l}51.0 \\
\pm 2.5\end{array}$ & $\begin{array}{c}7.6 \\
\pm 0.4\end{array}$ & $\begin{array}{l}166.2 \\
\pm 2.6\end{array}$ & $\begin{array}{l}1789.0 \\
\pm 13.5\end{array}$ & $\begin{array}{c}1600.5 \\
\pm 11.7\end{array}$ & - & - \\
\hline & $\begin{array}{l}\text { Mistrzejowice } \\
\text { osiedle } \\
\text { Tysiąclecia }\end{array}$ & $\begin{array}{l}35.5 \\
\pm 2.4\end{array}$ & $\begin{array}{l}27.6 \\
\pm 2.1\end{array}$ & $\begin{array}{c}207.6 \\
\pm 9.2\end{array}$ & $\begin{array}{l}122.2 \\
\pm 6.5\end{array}$ & $\begin{array}{l}772.6 \\
\pm 10.7\end{array}$ & $\begin{array}{l}28.1 \\
\pm 1.5\end{array}$ & $\begin{array}{l}56.1 \\
\pm 2.0\end{array}$ \\
\hline & Mean & 104.95 & 69.18 & 228.3 & 539.4 & 1317.9 & 125.0 & 85.50 \\
\hline \multirow{4}{*}{$\begin{array}{l}\text { Small } \\
\text { town }\end{array}$} & Krzeszowice & $\begin{array}{l}51.9 \\
\pm 3.5\end{array}$ & $\begin{array}{l}47.3 \\
\pm 2.1\end{array}$ & $\begin{array}{l}266.1 \\
\pm 4.5\end{array}$ & $\begin{array}{l}55.8 \\
\pm 2.1\end{array}$ & $\begin{array}{c}803.8 \\
\pm 6.6\end{array}$ & $\begin{array}{l}38.2 \\
\pm 1.6\end{array}$ & $\begin{array}{l}35.3 \\
\pm 1.3\end{array}$ \\
\hline & Brzesko & $\begin{array}{l}97.4 \\
\pm 3.8\end{array}$ & $\begin{array}{l}153.3 \\
\pm 4.3\end{array}$ & $\begin{array}{l}485.4 \\
\pm 5.5\end{array}$ & $\begin{array}{l}141.2 \\
\pm 4.1\end{array}$ & $\begin{array}{c}2014.5 \\
\pm 17.2\end{array}$ & - & $\begin{array}{l}170.8 \\
\pm 4.4\end{array}$ \\
\hline & Wieliczka & $\begin{array}{l}30.5 \\
\pm 1.2 \\
\end{array}$ & $\begin{array}{r}24.3 \\
\pm 1.1 \\
\end{array}$ & $\begin{array}{c}239.8 \\
\pm 1.9 \\
\end{array}$ & $\begin{array}{l}125.5 \\
\pm 2.4 \\
\end{array}$ & $\begin{array}{c}2675.0 \\
\pm 14.5 \\
\end{array}$ & - & - \\
\hline & Mean & 59.93 & 74.97 & 330.4 & 107.5 & 1831.1 & 38.20 & 103.0 \\
\hline \multirow{3}{*}{ Village } & Przysietnica & $\begin{array}{l}28.3 \\
\pm 1.1 \\
\end{array}$ & $\begin{array}{l}24.7 \\
\pm 0.6 \\
\end{array}$ & $\begin{array}{c}308.6 \\
\pm 1.8 \\
\end{array}$ & $\begin{array}{l}37.8 \\
\pm 0.9 \\
\end{array}$ & - & $\begin{array}{l}64.1 \\
\pm 1.7 \\
\end{array}$ & $\begin{array}{l}71.8 \\
\pm 2.4 \\
\end{array}$ \\
\hline & $\begin{array}{l}\text { Białka } \\
\text { Tatrzańska }\end{array}$ & $\begin{array}{l}28.3 \\
\pm 2.0\end{array}$ & $\begin{array}{l}41.4 \\
\pm 1.5\end{array}$ & $\begin{array}{c}130.6 \\
\pm 3.1\end{array}$ & $\begin{array}{l}62.3 \\
\pm 2.1\end{array}$ & $\begin{array}{l}211.9 \\
\pm 2.9\end{array}$ & $\begin{array}{l}39.3 \\
\pm 2.4 \\
\end{array}$ & $\begin{array}{l}104.5 \\
\pm 2.9\end{array}$ \\
\hline & Mean & 28.30 & 33.05 & 219.60 & 50.05 & 211.90 & 51.70 & 88.15 \\
\hline \multicolumn{9}{|c|}{$\mathbf{N i}$} \\
\hline \multirow{6}{*}{ Kraków } & $\begin{array}{l}\text { al. Adama } \\
\text { Mickiewicza }\end{array}$ & $\begin{array}{l}16.1 \\
\pm 0.5 \\
\end{array}$ & $\begin{array}{c}6.5 \\
\pm 0.4\end{array}$ & $\begin{array}{l}22.5 \\
\pm 0.9\end{array}$ & $\begin{array}{l}18.9 \\
\pm 0.9\end{array}$ & $\begin{array}{l}24.5 \\
\pm 0.8\end{array}$ & $\begin{array}{l}27.7 \\
\pm 0.8\end{array}$ & - \\
\hline & $\begin{array}{l}\text { plac } \\
\text { Szczepański }\end{array}$ & - & $\begin{array}{c}9.9 \\
\pm 0.5\end{array}$ & $\begin{array}{l}10.5 \\
\pm 0.6\end{array}$ & $\begin{array}{c}8.4 \\
\pm 0.4\end{array}$ & $\begin{array}{l}20.2 \\
\pm 0.6\end{array}$ & $\begin{array}{c}133.2 \\
\pm 1.5\end{array}$ & - \\
\hline & ul. Łokietka & $\begin{array}{l}23.2 \\
\pm 0.6\end{array}$ & $\begin{array}{l}12.3 \\
\pm 0.7\end{array}$ & $\begin{array}{l}21.4 \\
\pm 0.5\end{array}$ & $\begin{array}{c}9.6 \\
\pm 0.4\end{array}$ & $\begin{array}{c}4.6 \\
\pm 0.4\end{array}$ & $\begin{array}{l}13.1 \\
\pm 0.5\end{array}$ & $\begin{array}{l}72.2 \\
\pm 1.3\end{array}$ \\
\hline & Nowa Huta & $\begin{array}{l}18.3 \\
\pm 0.4 \\
\end{array}$ & $\begin{array}{c}3.5 \\
\pm 0.3\end{array}$ & $\begin{array}{c}9.2 \\
\pm 0.5\end{array}$ & $\begin{array}{l}26.0 \\
\pm 0.8\end{array}$ & $\begin{array}{r}41.1 \\
\pm 0.9 \\
\end{array}$ & - & - \\
\hline & $\begin{array}{l}\text { Mistrzejowice } \\
\text { osiedle } \\
\text { Tysiąclecia }\end{array}$ & $\begin{array}{l}10.8 \\
\pm 0.8\end{array}$ & $\begin{array}{c}5.3 \\
\pm 0.5\end{array}$ & $\begin{array}{l}21.5 \\
\pm 0.9\end{array}$ & $\begin{array}{l}13.1 \\
\pm 0.8\end{array}$ & $\begin{array}{l}43.7 \\
\pm 1.3\end{array}$ & $\begin{array}{l}22.9 \\
\pm 0.9\end{array}$ & $\begin{array}{l}19.9 \\
\pm 0.8\end{array}$ \\
\hline & Mean & 17.10 & 6.90 & 18.65 & 16.90 & 28.48 & 21.23 & 46.05 \\
\hline \multirow{4}{*}{$\begin{array}{l}\text { Small } \\
\text { town }\end{array}$} & Krzeszowice & $\begin{array}{c}7.4 \\
\pm 0.5\end{array}$ & $\begin{array}{c}4.4 \\
\pm 0.3\end{array}$ & $\begin{array}{l}37.3 \\
\pm 0.9\end{array}$ & $\begin{array}{l}13.1 \\
\pm 0.7\end{array}$ & $\begin{array}{l}13.2 \\
\pm 0.7\end{array}$ & $\begin{array}{l}13.4 \\
\pm 0.6\end{array}$ & $\begin{array}{l}13.1 \\
\pm 0.5\end{array}$ \\
\hline & Brzesko & $\begin{array}{l}14.0 \\
\pm 0.6\end{array}$ & $\begin{array}{c}6.1 \\
\pm 0.5\end{array}$ & $\begin{array}{l}30.9 \\
\pm 1.1\end{array}$ & $\begin{array}{l}19.1 \\
\pm 0.8\end{array}$ & $\begin{array}{l}22.9 \\
\pm 0.9\end{array}$ & - & $\begin{array}{l}26.1 \\
\pm 0.8\end{array}$ \\
\hline & Wieliczka & $\begin{array}{l}23.0 \\
\pm 0.7\end{array}$ & $\begin{array}{l}10.9 \\
\pm 0.6\end{array}$ & $\begin{array}{l}12.6 \\
\pm 0.6 \\
\end{array}$ & $\begin{array}{l}18.6 \\
\pm 0.7\end{array}$ & $\begin{array}{l}27.8 \\
\pm 0.8 \\
\end{array}$ & - & - \\
\hline & Mean & 14.80 & 7.13 & 26.93 & 16.93 & 21.30 & 13.40 & 19.60 \\
\hline \multirow{3}{*}{ Village } & Przysietnica & $\begin{array}{c}8.8 \\
\pm 0.5 \\
\end{array}$ & $\begin{array}{c}6.1 \\
\pm 0.5\end{array}$ & $\begin{array}{l}29.0 \\
\pm 0.9 \\
\end{array}$ & $\begin{array}{c}3.9 \\
\pm 0.3\end{array}$ & $\begin{array}{l}39.9 \\
\pm 1.2 \\
\end{array}$ & $\begin{array}{l}17.9 \\
\pm 0.7\end{array}$ & $\begin{array}{l}32.7 \\
\pm 0.9\end{array}$ \\
\hline & $\begin{array}{l}\text { Białka } \\
\text { Tatrzańska }\end{array}$ & $\begin{array}{l}16.1 \\
\pm 0.8 \\
\end{array}$ & $\begin{array}{c}5.1 \\
\pm 0.4 \\
\end{array}$ & $\begin{array}{c}7.4 \\
\pm 0.5 \\
\end{array}$ & $\begin{array}{l}26.7 \\
\pm 0.8 \\
\end{array}$ & $\begin{array}{l}13.7 \\
\pm 0.6 \\
\end{array}$ & $\begin{array}{l}19.9 \\
\pm 0.6 \\
\end{array}$ & $\begin{array}{l}50.9 \\
\pm 1.2 \\
\end{array}$ \\
\hline & Mean & 12.45 & 5.60 & 18.20 & 15.30 & 26.80 & 18.90 & 41.80 \\
\hline
\end{tabular}


Deposited particulate matter comes into contact with people by inhalation, skin assimilation, or even oral ingestion. A comparison of trace element contents in deposited and suspended particulate matter in other cities around the world gave different results. This can be explained by various industrial activities, different sampling sites and methods as well as diversified analysis process leading to great changes in heavy metal concentrations for individual cities. In Southwest China, the trace element contents in suspended particulate matter were as follows: $44.1 \mathrm{mg} / \mathrm{kg}$ for $\mathrm{Cu}, 39.9 \mathrm{mg} / \mathrm{kg}$ for $\mathrm{Ni}, 38.1 \mathrm{mg} / \mathrm{kg}$ for $\mathrm{Pb}$, and $3.8 \mathrm{mg} \mathrm{kg}$ for $\mathrm{Cd}$ (Zeng et al. 2019). The results obtained for the particulate matter in Nigeria revealed the following concentrations of the selected metals, expressed in $\mathrm{mg} / \mathrm{kg}: \mathrm{Pb}$ (4.6-160.0), Cu (2.5-11.0), Ni (0.8-4.2), $\mathrm{Cd}$ - not detected (Akinade et al. 2018). The study on heavy metals in air dust in Winterthur, Switzerland revealed that the total metal contents ranged from 0.4 to $21 \mathrm{mg} / \mathrm{kg}$ for Cd, 25 to $204 \mathrm{mg} / \mathrm{kg}$ for $\mathrm{Cu}, 6$ to $58 \mathrm{mg} / \mathrm{kg}$ for $\mathrm{Ni}$, and 43 to $343 \mathrm{mg} / \mathrm{kg}$ for $\mathrm{Pb}$ (Furumai et al. 2004). In our study, the greatest amount of deposited particulate matter and metals present in it was determined in Kraków. The highest amount of cadmium, lead, copper and nickel in particulate matter was found at ul. Władysława Łokietka in Mistrzejowice, at al. Adama Mickiewicza, and at plac Szczepański in Kraków, respectively.

\section{Health risk assessment}

\section{Non-carcinogenic risk}

The highest health risk (highest HQ values) related to the cadmium content in particulate matter was observed in Przysietnica (5.42E-01 children, 5.82E-02 adults), where the risk values were closest to permissible ones, and the lowest health risk was observed in Białka Tatrzańska (1.53E-05 children, 2.40E-06 adults) (Tab. 5). The highest hazard quotient for children, associated with the presence of lead in particulate matter, was recorded in Kraków (5.46E-01), whereas the lowest in Brzesko (9.82E-02). The HQ for adults reached the highest and the lowest values in Kraków: the Mistrzejowice District (5.92E-02) and at plac Szczepański (1.18E-03), respectively (Tab. 5). The highest health risk related to the copper content in particulate matter was observed in Wieliczka (2.64E-02 children, 9.53E-02 adults), where the risk values were closest to permissible ones, and the lowest health risk was observed in Kraków (2.71E-04) (Tab. 5). In the case of nickel, the highest value of non-carcinogenic risk for children was determined in Kraków (1.30E-01), and the lowest in Przysietnica (9.05E-08). For adults, the highest HQ was also recorded in Kraków (1.25E-02), and the lowest in Przysietnica (2.65E-04) (Tab. 5). Taking into account the values of non-carcinogenic risk associated with exposure to individual metals, it can be stated that this risk is acceptable both in Kraków and in other parts of Małopolska, both for children and adults, as these values are not equal to or higher than 1 . Regardless of the location, children are most exposed to negative health effects.

\section{Carcinogenic risk}

The carcinogenic risk related to the presence of lead in the air at all studied sites was at an acceptable level (Tab. 6). The total carcinogenic risk for all routes of exposure to cadmium indicated the risk of cancer in children and adults, with children more exposed. The carcinogenic risk values for Cd were also acceptable, but higher than for lead. The carcinogenic risk values were particularly high for children in Brzesko, Wieliczka and Przysietnica (Tab. 6). Regardless of the location and elements, the highest risk values occurred for exposure by ingestion, and the lowest by inhalation of the particulate matter (Tab. 7). Heavy metals, including cadmium, pose a special risk to health because their effects are not immediate and they can take many years to appear. For example, cadmium accumulates in the lungs, kidneys, adrenal glands and liver and causes damage to these organs as well as hypertension, deformation of bones, neoplastic lesions and infertility. There are several causes of air pollution in Kraków: emissions from residential, municipal and industrial sectors, unfavorable location of the city, too many windless days, and development of ventilation channels. To summarize this study, it can be concluded that the assessment of health risks resulting from heavy metal air pollution will be helpful in making management decisions on air quality programs for large cities. 
Table 5

Non-carcinogenic risk values for metals in Małopolska

\begin{tabular}{|c|c|c|c|c|c|c|c|c|c|}
\hline \multirow{2}{*}{\multicolumn{2}{|c|}{ Location }} & \multicolumn{2}{|c|}{ Cd } & \multicolumn{2}{|c|}{$\mathbf{P b}$} & \multicolumn{2}{|c|}{$\mathrm{Cu}$} & \multicolumn{2}{|c|}{$\mathrm{Ni}$} \\
\hline & & \multirow{2}{*}{$\begin{array}{c}H Q_{\text {all }}{ }^{*} \\
\text { Child }\end{array}$} & \multirow{2}{*}{$\begin{array}{c}H Q_{\text {all }} \\
\text { Adult }\end{array}$} & \multirow{2}{*}{$\begin{array}{c}H Q_{\text {all }} \\
\text { Child }\end{array}$} & \multirow{2}{*}{$\begin{array}{c}H Q_{\text {all }} \\
\text { Adult }\end{array}$} & \multirow{2}{*}{$\begin{array}{c}\begin{array}{c}H Q_{\text {all }} \\
\text { Child }\end{array} \\
3.52 \mathrm{E}-03\end{array}$} & \multirow{2}{*}{$\begin{array}{c}\begin{array}{c}H Q_{\text {all }} \\
\text { Adult }\end{array} \\
1.25 \mathrm{E}-02\end{array}$} & \multirow{2}{*}{$\begin{array}{c}\begin{array}{c}H Q_{\text {all }} \\
\text { Child }\end{array} \\
1.14 \mathrm{E}-01\end{array}$} & \multirow{2}{*}{$\begin{array}{c}H Q_{\text {all }} \\
\text { Adult }\end{array}$} \\
\hline \multirow{3}{*}{ Kraków } & mean & & & & & & & & \\
\hline & $\max$ & $1.13 \mathrm{E}-01$ & $1.21 \mathrm{E}-02$ & $5.46 \mathrm{E}-01$ & $5.92 \mathrm{E}-02$ & $2.22 \mathrm{E}-02$ & $8.03 \mathrm{E}-02$ & $1.30 \mathrm{E}-01$ & $1.25 \mathrm{E}-02$ \\
\hline & $\min$ & $4.91 \mathrm{E}-03$ & $5.27 \mathrm{E}-04$ & $1.09 \mathrm{E}-02$ & $1.18 \mathrm{E}-03$ & $2.24 \mathrm{E}-05$ & $2.71 \mathrm{E}-04$ & $2.46 \mathrm{E}-02$ & $6.75 \mathrm{E}-03$ \\
\hline \multirow{3}{*}{ Krzeszowice } & mean & $3.62 \mathrm{E}-02$ & $3.88 \mathrm{E}-03$ & $1.35 \mathrm{E}-01$ & $1.40 \mathrm{E}-02$ & $1.81 \mathrm{E}-03$ & $6.52 \mathrm{E}-03$ & $3.19 \mathrm{E}-03$ & $1.00 \mathrm{E}-03$ \\
\hline & $\max$ & $9.41 \mathrm{E}-02$ & $1.01 \mathrm{E}-02$ & $2.55 \mathrm{E}-01$ & $2.76 \mathrm{E}-02$ & $7.93 \mathrm{E}-03$ & $2.86 \mathrm{E}-02$ & $2.39 \mathrm{E}-02$ & $2.57 \mathrm{E}-03$ \\
\hline & $\min$ & $4.00 \mathrm{E}-05$ & $6.25 \mathrm{E}-06$ & $6.50 \mathrm{E}-02$ & $4.00 \mathrm{E}-03$ & $3.43 \mathrm{E}-04$ & $1.24 \mathrm{E}-03$ & $1.03 \mathrm{E}-07$ & $3.03 \mathrm{E}-04$ \\
\hline \multirow{3}{*}{ Brzesko } & mean & $6.75 \mathrm{E}-02$ & $7.23 \mathrm{E}-03$ & $1.47 \mathrm{E}-01$ & $1.60 \mathrm{E}-02$ & $4.96 \mathrm{E}-03$ & $1.79 \mathrm{E}-02$ & $4.35 \mathrm{E}-03$ & $1.37 \mathrm{E}-03$ \\
\hline & $\max$ & $2.00 \mathrm{E}-01$ & $2.14 \mathrm{E}-02$ & $2.25 \mathrm{E}-01$ & $2.44 \mathrm{E}-02$ & $1.99 \mathrm{E}-02$ & $7.17 \mathrm{E}-02$ & $1.98 \mathrm{E}-02$ & $2.13 \mathrm{E}-03$ \\
\hline & $\min$ & $4.17 \mathrm{E}-05$ & $6.52 \mathrm{E}-06$ & $9.82 \mathrm{E}-02$ & $1.06 \mathrm{E}-02$ & $5.12 \mathrm{E}-04$ & $1.85 \mathrm{E}-03$ & $1.42 \mathrm{E}-07$ & $4.17 \mathrm{E}-04$ \\
\hline \multirow{3}{*}{ Wieliczka } & mean & $9.55 \mathrm{E}-02$ & $1.02 \mathrm{E}-02$ & $1.89 \mathrm{E}-01$ & $2.05 \mathrm{E}-02$ & $6.24 \mathrm{E}-03$ & $2.25 \mathrm{E}-02$ & $4.08 \mathrm{E}-03$ & $1.28 \mathrm{E}-03$ \\
\hline & $\max$ & $3.07 \mathrm{E}-01$ & $3.29 \mathrm{E}-02$ & $4.29 \mathrm{E}-01$ & $4.65 \mathrm{E}-02$ & $2.64 \mathrm{E}-02$ & $9.53 \mathrm{E}-02$ & $1.78 \mathrm{E}-02$ & $1.91 \mathrm{E}-03$ \\
\hline & $\min$ & $6.87 \mathrm{E}-05$ & $1.07 \mathrm{E}-05$ & $1.59 \mathrm{E}-01$ & $1.72 \mathrm{E}-02$ & $2.39 \mathrm{E}-04$ & $8.63 \mathrm{E}-04$ & $2.57 \mathrm{E}-07$ & $7.53 \mathrm{E}-04$ \\
\hline \multirow{3}{*}{ Przysietnica } & mean & $1.59 \mathrm{E}-01$ & $1.71 \mathrm{E}-02$ & $1.29 \mathrm{E}-01$ & $1.39 \mathrm{E}-02$ & $8.83 \mathrm{E}-04$ & $3.19 \mathrm{E}-03$ & $4.01 \mathrm{E}-03$ & $1.54 \mathrm{E}-03$ \\
\hline & $\max$ & $5.42 \mathrm{E}-01$ & $5.82 \mathrm{E}-02$ & $2.82 \mathrm{E}-01$ & $3.05 \mathrm{E}-02$ & $3.04 \mathrm{E}-03$ & $1.10 \mathrm{E}-02$ & $2.09 \mathrm{E}-02$ & $3.53 \mathrm{E}-03$ \\
\hline & $\min$ & $1.05 \mathrm{E}-02$ & $1.13 \mathrm{E}-03$ & $3.29 \mathrm{E}-02$ & $3.66 \mathrm{E}-03$ & $2.43 \mathrm{E}-04$ & $8.79 \mathrm{E}-04$ & $9.05 \mathrm{E}-08$ & $2.65 \mathrm{E}-04$ \\
\hline \multirow{3}{*}{$\begin{array}{l}\text { Białka } \\
\text { Tatrzańska }\end{array}$} & mean & $5.43 \mathrm{E}-02$ & $5.83 \mathrm{E}-03$ & $1.16 \mathrm{E}-01$ & $1.26 \mathrm{E}-02$ & $8.71 \mathrm{E}-04$ & $3.15 \mathrm{E}-03$ & $4.36 \mathrm{E}-03$ & $1.37 \mathrm{E}-03$ \\
\hline & $\max$ & $1.89 \mathrm{E}-01$ & $2.03 \mathrm{E}-02$ & $2.36 \mathrm{E}-01$ & $2.55 \mathrm{E}-02$ & $2.09 \mathrm{E}-03$ & $7.55 \mathrm{E}-03$ & $3.25 \mathrm{E}-02$ & $3.50 \mathrm{E}-03$ \\
\hline & $\min$ & $1.53 \mathrm{E}-05$ & $2.40 \mathrm{E}-06$ & $4.16 \mathrm{E}-02$ & $4.51 \mathrm{E}-03$ & $2.79 \mathrm{E}-04$ & $1.01 \mathrm{E}-03$ & $1.21 \mathrm{E}-07$ & $3.53 \mathrm{E}-04$ \\
\hline
\end{tabular}

Table 6

Carcinogenic risk values for metals in Małopolska

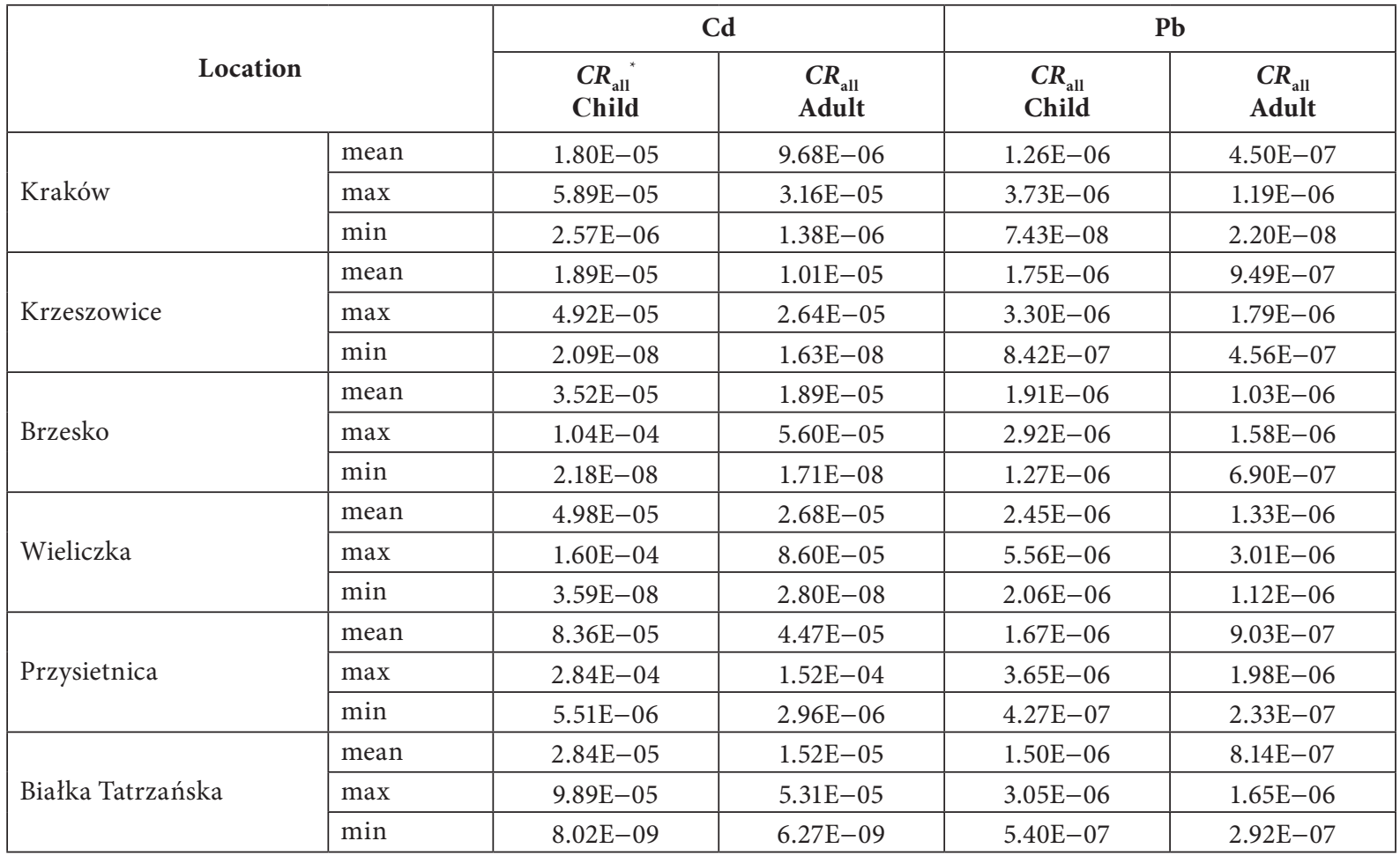

$$
{ }^{*} C R_{\mathrm{all}}=\Sigma C R_{\mathrm{ing}}+C R_{\mathrm{inhal}}+C R_{\mathrm{derm}} \text {. }
$$


Table 7

Mean carcinogenic risk values for $\mathrm{Cd}$ and $\mathrm{Pb}$ depending on the exposure route

\begin{tabular}{|l|c|c|c|c|}
\hline \multirow{2}{*}{ Exposure route } & \multicolumn{2}{|c|}{ Cd } & \multicolumn{2}{c|}{ Pb } \\
\cline { 2 - 5 } & $\begin{array}{c}\text { CR } \\
\text { Child }\end{array}$ & $\begin{array}{c}\text { CR } \\
\text { Adult }\end{array}$ & $\begin{array}{c}\text { CR } \\
\text { Child }\end{array}$ & $\begin{array}{c}\text { CR } \\
\text { Adult }\end{array}$ \\
\hline Ingestion & $1.80 \mathrm{E}-05$ & $9.64 \mathrm{E}-06$ & $1.03 \mathrm{E}-06$ & $5.51 \mathrm{E}-07$ \\
\hline Inhalation & $1.42 \mathrm{E}-09$ & $6.64 \mathrm{E}-10$ & $2.03 \mathrm{E}-09$ & $1.63 \mathrm{E}-09$ \\
\hline Dermal & $5.04 \mathrm{E}-08$ & $3.85 \mathrm{E}-08$ & $5.44 \mathrm{E}-07$ & $8.32 \mathrm{E}-08$ \\
\hline
\end{tabular}

\section{CONCLUSIONS}

1. The highest amount of deposited particulate matter and metals present in it was determined in Kraków. However, the largest deposition of particulate matter was observed in Kraków only in two periods: April/May and May/June. In the case of smaller towns and in rural areas, the amounts of particulate matter deposited remained at a similar level or even exceeded the amounts of particulate matter collected in Kraków.

2. In the case of non-carcinogenic risk associated with the presence of individual metals in particulate matter, HQ did not exceed 1 in any case. By contrast, in the case of lead in particulate matter, the carcinogenic risk did not reach $10^{-6}$ hence this risk is acceptable. The total carcinogenic risk for all routes of exposure to cadmium indicated the risk of cancer in children and adults, with children more exposed. However, the carcinogenic risk for cadmium was also acceptable.

The study was financed by the Ministry of Science and Higher Education of the Republic of Poland.

\section{REFERENCES}

Akinade S., Tesleem O., Oloruntola K. \& Günter Ch., 2018. Evaluation of pollution of soils and particulate matter around metal recycling factories in Southwestern Nigeria. Journal of Health and Pollution, 8, 17, 20-30. https:// doi.org/10.5696/2156-9614-8.17.20.

Anake W., Benson N., Tenebe I.T., Emenike Ch., Ana G.R. \& Zhang S., 2019. Chemical speciation and health risks of airborne heavy metals around an industrial community in Nigeria. Human and Ecological Risk Assessment: An International Journal, 25, 8, 2098-2115. https://doi.org/ 10.1080/10807039.2018.1504672.
Anderson J., Thundiyil J. \& Stolbach A., 2012. Clearing the Air: A review of the effects of particulate matter air pollution on human health. Journal of Toxicology, 8, 166-175. https://doi.org/10.1007/s13181-011-0203-1.

Anenberg S., Belova A., Brandt J. et al. 2016. Survey of ambient air pollution health risk assessment tools. Risk Analysis, 36(9), 1718-1736. https://doi.org/10.1111/risa.12540.

Ayangbenro A. \& Babalola O., 2017. A New strategy for heavy metal polluted environments: A review of microbial biosorbents. International Journal of Environmental Research and Public Health,14, 94. https://doi. org/10.3390/ijerph14010094.

Baran A., Czech T. \& Wieczorek J. 2014. Chemical properties and toxicity of soils contaminated by mining activity. Ecotoxicology 2, 7, 1234-1244. https://doi.org/10.1007/ s10646-014-1266-y.

Corrêa A., Testolin R., Torres M., Cotelle S., Schwartz J., Millet M. \& Radetsi M., 2017. Ecotoxicty assessment of particulate matter emitted from heavy-duty diesel-powered vehicles: influence of leaching condition. Environmental Science and Pollution Research, 24, 9399-9406. https://doi.org/10.1007/s11356-017-8521-8.

Du Y., Gao B., Zhou H., Ju X., Hao H. \& Yin S., 2013. Health risk assessment of heavy metals in road dusts in urban parks of Beijing. China. Procedia Environmental Sciences, 18, 299-309. https://doi.org/10.1016/j.proenv.2013.04.039.

Dziubanek G., Marchwińska-Wyrwał E., Piekut A., Rusin M. \& Hajok I., 2014. Zanieczyszczenia powietrza jako istotny modyfikowalny czynnik ryzyka zdrowotnego [Air pollution as a significant modifying health risk factor]. Hygeia Public Health, 49, 1, 75-80.

EEA, 2018. Air quality in Europe - 2018 report. EEA Report No 12/2018, European Environment Agency.

Furumai H., Aryal R.K. \& Nakajima F., 2004. Profile analysis of polycyclic aromatic hydrocarbons and heavy metals in size fractionated highway dust and runoff samples. In: Strecker E.W., Huber W.Ch. (eds.), Global Solutions for Urban Drainage: Proceedings of the Ninth International Conference on Urban Drainage, Reston, American Society of Civil Engineers, 1-13.

Gruszecka-Kosowska A., 2018. Assessment of the Kraków inhabitants' health risk caused by the exposure to inhalation of outdoor air contaminants. Stochastic Environmental Research and Risk Assessment A, 32, 485-499. https://doi.org/10.1007/s00477-016-1366-8.

Gruszecka-Kosowska A. \& Wdowin M. 2016. The mineralogy geochemistry and health risk assessment of deposited particulate matter (PM) in Kraków, Poland. Geology, Geophysics and Environment, 42, 4, 429-441. https://doi. org/10.7494/geol.2016.42.4.429. 
Hieu N.T. \& Lee B-K., 2010. Characteristics of particulate matter and metals in the ambient air from a residential area in the largest industrial city in Korea. Atmospheric Research. https://doi.org/10.1016/j.atmosres.2010.08.019.

Kicińska A. \& Bożęcki P. 2018. Metals and mineral phases of dusts collected in different urban parks of Krakow and their impact on the health of city residents. Environmental Geochemistry and Health, 40, 473-488. https://doi. org/10.1007/s10653-017-9934-5.

Kicińska A., 2019. Environmental risk related to presence and mobility of As, $\mathrm{Cd}$ and $\mathrm{Tl}$ in soils in the vicinity of a metallurgical plant - Long-term observations. Chemosphere, 236, 124308. https://doi.org/10.1016/j.chemosphere.2019.07.039.

Olszowski P., 2013. Comparison of the method of atmosperic deposition measurement. Proceedings of ECOpole, 7, 1, 385-381. https://doi.org/10.1039/B822330K.

Qi J., Li P., Li X., Feng L. \& Zhang M., 2005. Estimation of dry deposition fluxes of particulate species to the water surface in the Qingdao area, using a model and surrogate surfaces. Atmospheric Environment, 39, 2081-2088. https://doi.org/10.1016/j.atmosenv.2004.12.017.

Shaheen N., Shah M.H., Khalique A. \& Jaffar M., 2005. Metal levels in airborne particulate matter in urban Islamabad. Pakistan. The Bulletin of Environmental Contamination and Toxicology, 75, 4, 739-746. https://doi.org/10.1007/ s00128-005-0813-x.

Song B., Guo G., Lei M. \& Wang Y., 2018. Assessments of contamination and human health risks of heavy metals in the road dust from a mining county in Guangxi, China. Human and Ecological Risk Assessment, 24, 1606-1622. https://doi.org/10.1080/10807039.2017.1419815.

Sun G., Li Z., Liu T., Chen J., Wu T. \& Feng X., 2017. Metal Exposure and Associated Health Risk to Human Beings by Street Dust in a Heavily Industrialized City of Hunan Province, Central China. International Journal of Environmental Research and Public Health, 14, 261. https:// doi.org/10.3390/ijerph14030261.

Tai A.Y., Chen L.A., Wang X., Chow J.C. \& Watson J.G., 2017. Atmospheric deposition of particles at a sensitive alpine lake: Size-segregated daily and annual fluxes from passive sampling techniques. Science of the Total Environment, 579, 1736-1744. https://doi.org/10.1016/j.scitotenv. 2016.11.117.

Talbi A., Kerchich Y., Kerbachi R. \& Boughedaoui M. 2018. Assessment of annual air pollution levels with PM1, PM2.5, PM10 and associated heavy metals in Algiers, Algeria. Environmental Pollution, 232, 252-263. https:// doi.org/10.1016/j.envpol.2017.09.041.

Tomaszewska B. \& Olszowski T. 2012. Ilościowa i jakościowa ocena depozycji pyłu na obszarze wsi [Quantitative and qualitative assessment of the dust deposition on the rural area]. Proceedings of ECOpole, 6, 2, 609-619. https:// doi.org/10.2429/proc.2012.6(2)082.

US EPA, 2004. Risk Assessment Guidance for Superfund. Volume I: Human Health Evaluation. Manual - Part E, Supplemental Guidance for Dermal Risk Assessment. EPA/540/R/99/005, Office of Superfund Remediation and Technology Innovation, U.S. Environmental Protection Agency, Washington.

Wcisło E., Bronder J., Bubak A., Rodriguez-Valdés E. \& Gallego J.L.R., 2016. Human health risk assessment in restoring safe and productive use of abandoned contaminated sites. Environment International, 94, 436-448. https://doi.org/10.1016/j.envint.2016.05.028.

Wieczorek J., Baran A., Mazurek R., Urbański K. \& Klimkowicz-Pawlas A., 2018. Assessment of the pollution and ecological risk of lead and cadmium in soils. Environmental Geochemistry and Health, 40, 2325-2342. https:// doi.org/10.1007/s10653-018-0100-5.

Zeng J., Han G., Qixin Wu Q. \& Tang Z., 2019. Heavy metals in suspended particulate matter of the Zhujiang River, Southwest China: contents, sources, and health risks. International Journal of Environmental Research and Public Health, 16(10), 1843. https://doi.org/10.3390/ijerph16101843.

Zhou P., Guo J., Zhou X., Zhang W., Liu L., Liu Y. \& Lin K., 2018. PM2.5, PM10 and health risk assessment of heavy metals in a typical printed circuit noards manufacturing workshop. Journal of Environmental Sciences, 26, 2018-2026. https://doi.org/10.1016/j.jes.2014.08.003. 